\title{
Crude oil Price Fluctuations to Kazakhstan Economic Impact Analysis
}

\author{
LI Cuiping \\ China Academy of Xinjiang University of Finance and Central Asia Economic and Trade (Xinjiang \\ Urumqi 830012) \\ 335300609@qq.com
}

Key words:oil price fluctuation;Economic growth;VAR model;Impulse response;Granger reason

Abstract:using the VAR model, this paper builds the crude oil price fluctuation and economic growth of kazakhstan, monetary policy, price level, the unemployment rate and other variables and the static relationship between oil price fluctuations on the influence law of kazakhstan's important economic variables such as economic growth, Granger causality analysis shows that the international oil price fluctuations is kazakhstan's economic growth rate, money supply, price levels, unemployment, etc. The Granger cause of the change of the economic indicators. Through the VAR model and impulse response analysis, the impact of oil price fluctuation on kazakhstan national economy mainly include: gross domestic product (GDP) will not change, but can make the economic growth is slowing, through the pull of aggregate supply and cost reduce two ways to make price level rise, increase long-term unemployment, and the effects of monetary policy effectiveness.Overall, although the international price of crude oil and kazakhstan, the relationship between economic variables are complex, but through the automatic adjustment and the government's macroeconomic regulation and control of the market, oil prices, money supply, price level, Economic growth and unemployment, which is composed of five relevant economic variables such as kazakhstan economic system is relatively stable in the long run.

\section{Introduction}

Volatility of oil prices on a country's macroeconomic can have much impact, has become the current ha countries and countries around the world are the focus of attention problems.Scholars from the perspective of two different theoretical and empirical analyses the economic impact of oil price fluctuation is studied.Cunado (2003) in the European and American developed countries as the main research object, and the results of the study concluded that crude oil price fluctuation has significant effect on the economy, mainly manifested in the economic growth, inflation and unemployment, etc.;Herrera through empirical analysis that the VAR model, crude oil price fluctuations in macroeconomic activities will cause a slight short wave, and a perfect system of monetary policy to produce such volatility will be a leveling; in the price of crude oil influence on a country's economy, should consider the mutual complementary and substitution effect between economic variables.

\section{The research methods}

In this paper, the main research methods are VAR (vector autoregression), Granger causality test, impulse response function and variance decomposition.VAR model was established based on the statistical nature of the data model, it is the system of each endogenous variable as the lag value of the all the endogenous variables in the system function to construct the model of multivariate time series to predict system and stochastic disturbance on the variable system dynamic effect of the 
VAR model requires that the data is stable, so should the stationarity test sequence.Have a lag phase $\mathrm{p}$ and $\mathrm{n}$ variables VAR model is as follows:

$$
Y t=\alpha+\sum_{i=0}^{p} \beta_{i} Y_{t-i}+\varepsilon_{t}
$$

In the empirical analysis of the VAR model, based on the VAR model, impulse response function and variance decomposition can be used to analyze the static relationship between variables.And through the impulse response function, test oil price fluctuation to kazakhstan the duration of a number of economic variables and impact strength.By the size of the variance contribution, measure the random disturbance of relative important degree of the economic variables, which determine the influence of oil price fluctuations to kazakhstan's economic situation.

\section{The selection of variables}

In this paper, crude oil price fluctuations and kazakhstan industrial output, price level, the static relationship between money supply and the unemployment rate, selection of variables is as follows:

(1) oil (FFOB).Kazakhstan is the world's oil exporter, in terms of trade, kazakhstan crude oil and refined products, the main export way is to spot trading., according to the pricing model, the domestic price of crude oil is determined by the international oil price.

(2) the industrial added value growth rate (IND).Economic growth rates can be used to measure a country's GDP or industrial added value, and value added of industry to GDP has a good substitute.If the industry increased, this phenomenon will come to the conclusion that is already available in the literature, but through the literature, actually this kind of phenomenon is not in accordance with some countries.

(3) the consumer price index (PI).Consumer price index (CPI )can fully reflect the whole situation of consumers' purchasing power and economy.

(4) the M2 average annual growth rate (M2).Based on M2 growth rate of the LBL as monetary policy intermediary goal, as the observable target.

(5) the unemployment rate (UEM).This article selects kazakhstan's official unemployment statistics for a long time, in addition, the world bank official unemployment of annual data.

Third, the empirical analysis

\section{The unit root test}

Avoid using nonstationary variables may cause the fallacy of regression, we first use ADF method the stability of variable unit root test,

Inspection equation is as follows:

We through ADF method, the industrial added value growth rate LNIND LNLBL, oil prices LNFOB, broad money growth, LNCPI price level and unemployment LNUEM variables such as implementing stationarity test sequence.Take a test at 5\% significant level nowadays LNFOB, LNIND, LNUEM are smooth, these variables are unit root, andThe sequence of first order difference of ADF value is under the level of 5\% rejected the null hypothesis of unit root, clear all variables are I (1) sequence.But the first order difference sequence is stable under the 5\% significant level.Therefore, in the following analysis, adopt the three variables to analyze the difference of sequences, and before the variable name "D," said the first order difference. 


\section{The Granger causality test}

Through the Granger causality test, get the following conclusion:

By the above analysis we can draw such a conclusion: although the price of brent crude and kazakhstan's economic variables is complicated, in general, by oil, industrial growth rate, price level, monetary policy, the five economic variables such as the unemployment rate of macroeconomic system is relatively stable.

By AR characteristic polynomial inverse root figure of VAR model, the following conclusions:(1) the crude oil price fluctuations on the influence of the industrial added value growth rate., oil price fluctuations will not make the GDP increase or decrease, only to change the country's economic growth speed, part of the industry in the expansion in recent years, offset the shrinking supply growing demand for the crude oil price fluctuations brings the effect, make the country's crude oil price fluctuations will not have negative impact on industrial production.(2) the influence of the crude oil price fluctuation on monetary policy., as the oil exporter, lower oil prices will reduce more foreign exchange income, cause its international payments imbalances, in order to reduce oil trade in large deficits, admire the people's bank of China needs to implement expansionary monetary policy, reduce domestic interest rates to curb domestic capital outflow.(3) the impact of oil price fluctuations to employment.Lower oil prices will make the production of crude oil enterprises suffer from economic loss, thus reducing the jobs. The fall in the price of crude oil, the economic growth is slowing, causing unemployment, in the long run, the unemployment rate will increase.

\section{The impulse response analysis}

According to the building of the VAR model, can draw various kinds of impulse response function, this article build LNCPI LNIND industrial added value growth rate and price level fluctuations in a unit of crude oil price fluctuations of impulse response function, standard deviation of the crude oil prices have a unit positive impact, and starting from 1) caused the acceleration of industrial growth, reduce gradually, after accelerate again, starting from 5 oil price shocks to gradually reduce the influence of industrial growth, from 8 to basic stability, to this, a reasonable explanation for, due to the rigid consumption, oil prices fell, the initial consumption will be reduced, but has effect on the crude oil price sensitivity, after spending the increase of the relative, as oil prices impact generated by gradually disappear, again steady economic growth, therefore, oil price fluctuations will pose opposite impact to the growth rate of output, and the impact will gradually disappear.In the first 3 midterm, basically be cause prices to rise, after 6 , oil is the most basic raw materials, industrial production department a drop in oil prices will inevitably results in the decrease of the cost of oil related industry chain, eventually lead to deflation.

\section{Conclusion}

(1) oil price fluctuations will not make the GDP increase or decrease, only to change the country's economic growth speed, part of the industry in the expansion in recent years, basic offset shrinking supply growing demand for the crude oil price fluctuations brings the effect, make the country's crude oil price fluctuations will not be a negative impact on industrial output, its impact on the economy is mainly reflected in on the volatility of economic growth.(2) the influence of the crude oil price fluctuation on monetary policy., as the oil exporter, lower oil prices will reduce more foreign exchange income, to make up for the oil trade in large deficits, avoid its balance of payments imbalances, admire the people's bank of China needs to implement expansionary 
monetary policy, reduce domestic interest rates to curb domestic capital outflow.(3) the impact of oil price fluctuations to employment.Lower oil prices will make the production of crude oil enterprises suffer from economic loss, thus reducing the jobs.The fall in the price of crude oil, the economic growth is slowing, causing unemployment, in the long run, the unemployment rate will increase.

\section{Acknowledgements}

(1)Xinjiang University of Finance and Economics PhD Student Research Innovation Project (XJUFE2015K002) 《The " Silk" road economic belt under the framework of financial support research energy coopertion》; (2)China's National Social Science Fund Projects ( 16 BJY171)《Build based on xinjiang radiation asia-europe cross-border cotton futures market research $》$.

\section{References:}

[1] Zhang Qingjun, international crude oil price fluctuations on the impact of the RMB exchange rate effect research [C], conference papers, 2011.5

[2] li wei, crude oil price fluctuations in macroeconomic - transmission mechanism and the influence of national practice research [D], dissertation, fudan university, 2008

[3] Yang Zhen, international crude oil futures prices impact on the economy of our country's empirical research [D], dissertation, foreign economic and trade university in 2013

[4] jian-ling jiao, econometric analysis model of oil price and its empirical study [D], dissertation, university of science and technology of China, 2005

[5] wuri wave, the analysis of characteristics of international crude oil prices and its impact on the world economy [C], conference papers, 2008.10

[6] huan-ping shi, Gao Yan: an empirical study of Chinese currency structure and price changes [J], journal of east China jiaotong university, 2014.3

[7] zhen-xin wu, Xue Bing Wang Shuping. Based on the VAR model of oil price fluctuation on China's economic impact analysis [J]. Journal of management science in China, 2011 (1) : 21-08

[8] lan-fang cheng, clean pigeon, international crude oil price fluctuations on the analysis of the conductive effect of price [J], issue price, 2013.12

[9] zhi-guo li, Guo Jinggang, international crude oil price fluctuations on China's macroeconomic transmission and influence - the empirical analysis based on SVAR model [J], economic fabric is 2013.4

[10] liu's win, on the impact of the international oil price fluctuations on China's price level research [D], dissertation, hunan university, 2010 